\title{
UN FÉNIX PARA LOS AÑOS DE HIERRO. LOPE DE VEGA Y LA ORDEN DE LOS DOMINICOS
}

\author{
POR \\ JULIÁN GONZÁLEZ-BARRERA ${ }^{1}$ \\ Universidad de Sevilla - Instituto de Estudios culturales cristianos, Tokio
}

\section{RESUMEN}

En 1618 Lope de Vega publicaba El triunfo de la fe en los reinos del Japón, una historia de mártires inspirada en la relación de un misionero dominico en aquellas lejanas tierras. El propio poeta confiesa que le fue enviada desde Manila, pero no aporta más detalles. Ahora, por primera vez, todo el proceso de encargo se desvela: qué frailes participaron, cómo le convencieron y por qué necesitaron de la ayuda de un poeta de vida y ejemplo no precisamente piadoso.

PALABRAS CLAVE: Lope de Vega; Orden de Santo Domingo; jesuitas; Japón; odium theologicum.

\section{A PHOENIX FOR THE IRONCLAD YEARS. LOPE DE VEGA AND THE DOMINIC ORDER}

\section{ABSTRACT}

In 1618 Lope de Vega published El triunfo de la fe en los reinos del Japón, a martyr's history inspired in a relación written by a Dominic missionary in those far lands. The poet himself confesses that it was send it to him from Manila, but he says nothing more. Now, for the first time, the whole process is revealed: which friars participated, how they convinced him and why they needed the help of a poet of life and example not so pious precisely.

KEY WORDS: Lope de Vega; Order of Saint Dominic; Jesuits; Japan; odium theologicum.

Cómo CITAR ESTE ARTículo / CITATION: González-Barrera, J. 2017. «Un fénix para los años de hierro. Lope de Vega y la Orden de Ios Dominicos». Hispania Sacra 69, 139: 233-245. doi: 10.3989/hs.2017.016

Recibido/Received 13-01-2015

Aceptado/Accepted 29-09-2015
Era un día de agosto de 1617 cuando Lope de Vega tomaba la pluma para escribirle a su mecenas, el duque de Sessa. Entre la alegría y el recato le informaba del embarazo de su amante, Marta de Nevares, y de improviso le anunciaba su siguiente obra para la imprenta:

Mi estudio estos días ha sido una historia de unos mártires, o digamos Relación, a que me ha obligado haberme escrito unos padres desde el Japón. Serán cincuenta hojas, que voy ya en los fines. Pienso que agradará, que también sé yo escribir prosa historial cuando quiero. ${ }^{2}$

Aquella "historia de unos mártires» acabaría siendo El triunfo de la fe en los reinos del Japón (Madrid, 1618), publicada en plena vorágine por la circulación de la Spongia, ${ }^{3}$ una de las controversias literarias más furibundas que conoció el Madrid de los Austrias. Una batalla de la que saldría victorioso pero sin triunfo, pues a la postre terminaría perdiendo la guerra. Sin embargo, de manera consciente o no, al aceptar ese encargo Lope se ponía al servicio de una causa o partido inmerso en otra polémica aun de mayor calado, pues no se disputaba en la arena poética sino en las cortes europeas, con Roma como punto cardinal. Un conflicto teológico que amenazaba con hacer temblar los cimientos de la Iglesia católica y que tenía al Japón como coartada.

1 jgonbar@us.es/ORCIDiD:http://orcid.org/0000-0002-9856-8053

2 Vega 2008: 360. Para un análisis en profundidad de la obra (estructura, personajes, ideas, etc.), remitimos a la excelente edición de J. S. Cummins.

3 Lamentablemente, la Spongia está hoy perdida y solo contamos con los pasajes sueltos que se reproducen en la Expostulatio Spongiae. 


\section{LA GUERRA LITERARIA DE LA SPONGIA}

El trienio 1616-1618 fue especialmente delicado para Lope de Vega. En la cúspide de su fama literaria y ya considerado por muchos como un mito viviente, la circulación de las Soledades de Luis de Góngora había puesto en marcha una estrepitosa controversia que ponía en cuestión los laureles del llamado Fénix de los Ingenios. ${ }^{4}$ El espacio poético de la época se fragmentó en dos bandos irreconciliables, lopistas y gongoristas, que andaban a la gresca como si de Capuletos y Montescos se tratase. En otoño de 1616, un cauteloso Lope había eludido una segura humillación al no asistir a la justa poética por la Virgen del Sagrario en Toledo, pero no logró evitar una exaltación pública del gongorismo ante la presencia de los Reyes de España. Aquello fue un golpe para la moral del Fénix y los suyos. Delante de la Familia Real se consagraba una terca realidad: el gusto por la «nueva poesía» de Góngora y sus seguidores contaba con el favor político de la corte. El año siguiente no sería mejor. En 1617 las malas noticias se precipitaban en cascada. Mientras Lope porfiaba en su quimera de alcanzar el puesto de Cronista Real, ${ }^{5}$ Góngora lograba una capellanía de honor de manos del mismísimo duque de Lerma, el todopoderoso valido. Por otra parte, a finales de verano debió aparecer por Madrid el Examen del Antídoto del abad de Rute, ${ }^{6}$ una defensa categórica de la "nueva poesía» que pretendía silenciar el Antídoto contra la pestilente poesía de las Soledades del sevillano Juan de Jáuregui. ${ }^{7}$ Sin duda, lo consiguió, pero fuera la causa o la consecuencia, lo cierto es que poco a poco la lista de aliados de Lope fue menguando e incluso hubo alguna sonora sorpresa. ${ }^{8}$

Sin embargo, no sería el único golpe que traería la segunda mitad del año. Dentro de un ambiente tan favorable para los acólitos de la «nueva poesía», surgirá la figura ambiciosa de un maestro de latines de la Universidad Complutense, que había intervenido por cierto en aquel certamen por la Virgen del Sagrario el año anterior. Su participación discreta, sin pena ni gloria, pero en estilo gongorino, dio pública fe de lo que en verdad ya defendía en privado, pues sabemos que era un asiduo de tertulias, academias y contubernios literarios. Forastero en Madrid, había llegado desde Burgos algunos años atrás y malvivía compaginando su modesto trabajo como repetidor de gramática latina -el escalón más bajo en la docencia de la época- con sus estudios de Teología en la misma universidad. Su nombre era Pedro Torres Rámila.

4 La polémica literaria por las Soledades arrancaría hacia 1613 , pero hasta prácticamente finales de 1615 y comienzos de 1616 no se produce una escalada de las hostilidades entre ambos bandos (Daza 2014).

5 Bershas 1963.

6 El Examen tiene como terminus post quem el 25 de julio de 1617 (López-Bueno 201: 250). Asimismo véase el último análisis de Elvira 2014.

En septiembre de 1617, Lope escribía al Duque: «La deste libro [Examen] es notable, el autor debe de haber querido darse a conocer por él, más que decir lo que siente. Creo que ha de levantar alguna borrasca porque el Jáuregui sabe y no sufre. Yo pienso estar a la mira del suceso, dejando el juicio destas cosas a la critiquería de la Corte donde tantos dicen que saben que no sé para qué hay libros ni maestros» (Vega 2008: 381).

8 Acaso las deserciones más sonadas fueron las del propio Juan de Jáuregui y fray Hortensio Paravicino. Sobre la traición de este último, véase González-Barrera 2009.
Por si fuera poco todo lo dicho, la ocasión era más que propicia, acaso única, pues Lope tenía otros frentes abiertos. En lo personal, el 12 de agosto nacía una hija de su relación con Marta de Nevares, para mayor escándalo de la Villa y Corte. Ella era una mujer casada; él, un sacerdote ordenado. En lo profesional, la amenaza de reforma que pendía sobre los corrales de comedias y el cambio progresivo en las tendencias escénicas, con el uso de tramoyas como caballo de batalla, lo disgustaba notablemente, pues siempre dejó por escrito su reticencia a adaptarse a los nuevos tiempos. ${ }^{9}$

Así pues, la sed propia de notoriedad y el hambre ajena de bronca ${ }^{10}$ le impulsaron a escribir un libelo incendiario que vilipendiaba al Fénix como hombre y como poeta: la Spongia. ${ }^{11}$ La intención estaba clara: hacer leña del árbol caído y borrar el prestigio de Lope con aquella esponja. Unos modos tan agresivos como cobardes, pues se trataba de una supuesta edición francesa y el autor ocultaba su identidad bajo un anagrama: Trepus Ruitanus Lamira-Pedro Torres Rámila-. A juzgar por la reacción furibunda que llegó después, tuvo que ser un verdadero cataclismo. Apenas un sencillo maestro, pero profesor universitario al fin y al cabo, aquella crítica desde el poste podía ser un acicate para otros, en un ámbito como el académico que había sido tradicionalmente favorable. Asimismo, el hecho de que la Spongia estuviera escrita en latín le otorgaba una dimensión internacional que hacía peligrar el mito del Fénix más allá de las fronteras españolas. En suma, una grave amenaza que no debía quedar sin respuesta. Y llegaría al año siguiente, bajo el título de Expostulatio Spongiae (1618), un proyecto clandestino a varias manos -aunque supervisado por el propio Lope-, cuyo objetivo era imitar la forma y destruir el contenido de la Spongia. ${ }^{12}$

En este ambiente tan tenso, convulso y hasta violento, ${ }^{13} \mathrm{a}$ la par que desde el bando lopista se gestaba una contestación que desterrara cualquier sombra de duda o mancha sobre el Fénix, tuvo que producirse el primer contacto con la Orden de los dominicos y el consabido encargo de una historia de los mártires del Japón.

\section{HISTORIA DE UN ODIUM THEOLOGICUM: JESUITAS VS ÓRDENES MENDICANTES}

Si en Madrid lopistas y gongoristas andaban a la gresca por coronar al mejor poeta de España, en Roma se disputaban laureles de otra naturaleza. Desde su misma fundación, la

9 Recuérdese el prólogo a la Parte XVI (1621), que lleva como subtítulo: «Quejas del teatro contra las comedias de tramoya». Para saber más sobre la actitud de Lope ante las innovaciones tecnológicas, véase Asensio 1981.

10 Se trata de una de las teorías que defendió Entrambasaguas en su día, que Torres Rámila fue incitado a escribir por el mal consejo de algunos ingenios contrarios a Lope, como Cristóbal Suárez de Figueroa (Entrambasaguas 1946, I: 286-287).

11 Sabemos que la Spongia se ocupó de satirizar la vida privada de Lope, su teatro y muchas -por no decir prácticamente todas- de sus grandes obras hasta la fecha: La Dragontea, la Arcadia, La hermosura de Angélica, la Jerusalén conquistada y el Isidro, sin descontar un posible protagonismo de El peregrino en su patria, aunque fuera de soslayo.

12 Véase la primera traducción completa de la Expostulatio en González-Barrera 2011. En otros lugares, véase Tubau 2010.

${ }_{13}$ En más de un lugar de la Expostulatio Spongiae se pueden leer veladas amenazas de muerte para Pedro Torres Rámila (Ibídem: 12-13). 
Compañía de Jesús se había visto envuelta en la polémica y su relación con las otras órdenes religiosas era cuanto menos difícil. No obstante, cabe señalar que la labor misionera en el Asia fue la punta de lanza de una disputa teológica que hacía temblar los cimientos de la Iglesia Católica.

Japón había sido descubierta prácticamente al tiempo de la fundación de la Compañía y los primeros misioneros en llegar habían sido San Francisco Javier y sus compañeros, por lo que los jesuitas sentían un vínculo particular con aquellas tierras. ${ }^{14}$ Además, al contrario que en otras zonas asiáticas, como la India, la misión evangelizadora estaba cosechando sus frutos, por lo que el impulso jesuita no paraba de crecer.

El entusiasmo sincero de sus cartas, historias y relaciones sobre Japón, que se publicaban en Europa como parte de la propaganda jesuítica, atrajo pronto la atención de los españoles, que se vieron con el mismo derecho que los Padres y sus patrocinadores, los portugueses, para evangelizar aquellas tierras y, claro está, disfrutar también de la prosperidad del comercio con aquel país. Los jesuitas representaban a Portugal, aunque contaran con un buen número de españoles e italianos entre sus filas. A nivel administrativo, la misión dependía de la India y era a través de la ruta Lisboa-Goa-Nagasaki como llegaban a las costas japonesas. Por el contrario, agustinos, franciscanos y dominicanos eran españoles en su mayoría, consideraban al Rey de España como su señor natural y ejemplificaban una política evangelizadora que la Monarquía Hispánica ya había puesto en práctica en otros lugares del mundo. Por consiguiente, conviene recordar que a la sombra de estos misioneros caminaban los intereses políticos, militares y económicos de cada una de estas naciones. ${ }^{15}$

La anexión de Portugal de 1580 no sosegó el statu quo. El brazo imperial no alcanzaba las remotas posesiones lusas, que solo reconocían la autoridad española de forma nominal. En 1587, unos frailes escribían alarmados a Felipe Il para darle cuenta del absoluto desgobierno de Macao, donde solo mandaban los portugueses, apoyados por los jesuitas y sus aliados puntuales, los teatinos:

...si estuviésemos entre gente castellana, que conocen a V. M. y le tienen por su Rey y Señor, poca necesidad hubiera hacer nosotros esta diligencia y autorizarla con más firmas [...] mas aquí no le hay nadie que quiera y si alguno quiere, no osa por miedos falsos, pues posponen todas las cosas al mandato de su Visorrey, ora sea el que fuere, y a la obediencia de los padres teatinos, que en esto son el todo para persuadir por acá, que solo lo que ellos hacen es lo que conviene y no otra cosa [...] el temor que tenemos de no dar escándalo a los portugueses y a los dichos Padres, que los persuadan que luego se han de alzar, y lo mismo dicen de Japón (A. G. I., Filipinas, 79, no 16).

14 Véase Takizawa 2010. Asimismo, Hsu recoge los estudios más destacados acerca de las primeros contactos entre europeos y japoneses en una nota de obligada consulta en Hsu 2007, II: 227, n. 1. Para una visión diacrónica del cristianismo en Japón desde San Francisco Javier hasta nuestros días, véase Lázaro Pulido et al. 2011.

15 El hecho veraz de que los misioneros cumplían además tareas de espionaje era un secreto a voces que ninguna de las partes ocultaba. Desde Macao, el agustino fray Francisco Manrique escribía: «Le quiero avisar a V. M. las cosas que por acá pasan en tan lejas tierras, y V. M. nos tiene encargado y mandado le avisemos de todo, y que proveerá en ello lo que más convenga al servicio de Dios mío Creador y al de V. M.» (A. G. I., Filipinas, 79, no 16).
Deseosos de pasar a Japón, las Órdenes mendicantes presionarán a Felipe II para proceder cuanto antes con la labor misionera, aprovechando el clima de buen entendimiento. Desde Manila, la Corona española había iniciado ya los contactos diplomáticos con un tolerante Nobunaga primero y un dubitativo Hideyoshi después, pero los jesuitas reaccionaron rápido y el 28 de enero de 1585 consiguieron del papa Gregorio XIII la bula Ex pastorali officio, que les concedía de facto el monopolio espiritual sobre Japón. Un decreto papal que causó un profundo malestar entre los predicadores, que se vieron injustamente marginados. ${ }^{16}$

Las razones esgrimidas por la Compañía fueron de lo más variopintas. En su Sumario de las cosas de Japón (1583), el jesuita Alessandro Valignano defendía ante su superior en Roma hasta siete motivos para prohibir la llegada de otras órdenes. ${ }^{17}$ Entre sus muchos argumentos, justificaba su celo para no desorientar a los japoneses, que podrían creer que los diferentes atuendos de las órdenes representaban doctrinas separadas, como sucedía con los monjes budistas:

...una de las principales cosas que mueve a los japones a dejar sus sectas y a tomar nuestra ley es ver la diversidad que hay entre las sectas de los japones y entre los bonzos de unas mismas sectas [...] Y si ahora fuesen otras religiones con diversos hábitos, diverso modo de proceder y diversas opiniones, [...] sin duda creerían que somos de distintas sectas (ibídem: 143)

Por otra parte, se alegó que los años de experiencia sobre el terreno eran una garantía para convertir a un pueblo de carácter, mentalidad y tradiciones muy distintas a las otras naciones con las que agustinos, dominicanos y franciscanos estaban acostumbrados a tratar:

...las cualidades, costumbres y modo de proceder de los japones son tan diferentes y contrarias a las nuestras que no es aún Japón capaz del modo de proceder que tienen otras religiones de Europa [...] y no ayudarán para más que para deshacer lo que nosotros [...] pasando por muchas tribulaciones, vamos ahora haciendo (ibídem: 145-146).

Las Órdenes mendicantes no pudieron esquivar el veto de Roma, pero no dejaron de defenderse. Pronto replicaron que los jesuitas eran demasiado pocos para evangelizar ellos solos una tierra tan vasta como el Japón y que además se estaban enseñando doctrinas nuevas o sencillamente contrarias a la Fe católica, como el Probabilismo. Una protesta que con el paso del tiempo se acabó convirtiendo en una opinio malis. En 1598, fray Miguel de Benavides, obispo de Nueva Segovia -norte de Filipinas-, elevaba el tono de la crítica, tachándoles abiertamente de herejes:

Señor, V. M. sabe muy bien cuán peligrosas doctrinas son las de los Padres de la Compañía, que han querido inventar y sembrar en España y como si es verdad lo que oí decir huyeron el santo tribunal de la Inquisición [...] y quien huye de él no tiene muy segura su causa [...] lo que

16 No encontraron socorro en el Rey Católico. Un año después, Felipe II ordenaba a su virrey en la India, don Duarte de Meneses, que despachara una provisión para el cumplimiento de la bula papal. En abril de 1594, se promulgaba un decreto de similar naturaleza para las Filipinas.

17 Valignano 1954: 143-149. 
ahora se dice, esto del Japón, irá a los oídos de V. M. sin duda ninguna [..] oyendo [...] tantas cosas de unas partes y otras de estos Padres, viendo tanta y tan perniciosa novedad en sus doctrinas, considerando tan nueva manera de proceder sin óbolo, sin ayunos, sin otras asperezas (A. G. I., Filipinas, 76, № 38).

Al mismo tiempo comienza a oírse un argumento que se convertiría años más tarde en el caballo de batalla de toda la polémica por la pérdida espiritual del Japón: la peligrosa injerencia de la Compañía de Jesús en los asuntos internos del país. Unas maniobras políticas encaminadas a salvaguardar sus opulentos intereses económicos. Una acusación hiriente, pero no muy alejada de la realidad. EI propio Padre Valignano lo había admitido al declarar que en la misión japonesa después de Dios lo más importante era la Nao do trato. ${ }^{18}$ Además, en esta ocasión, el dedo acusador no pertenecía a un cualquiera, sino a todo un sobrino de san Ignacio de Loyola, aunque franciscano:

También hay grande defecto acerca del mercadear en muchas partes de las Indias Orientales. No hablo de los clérigos, que de esos hay mercaderes públicos, mas lo que yo con dolor de mi alma digo que aun esta pestilencia ha llegado hasta algunos religiosos, los cuales en muchas partes, máxime de Japón a la China, traen grueso desedificando no solo los portugueses y gentiles, mas también infamando al Padre Ignacio, su fundador y mi tío, como si él tal cosa hubiera enseñado. ${ }^{19}$

Entonces, en extrañas circunstancias, un 5 de febrero de 1597 Hideyoshi manda crucificar a seis franciscanos -cinco de ellos españoles- y veinte cristianos japoneses -diecisiete laicos y tres hermanos legos de los jesuitas- en la misma Nagasaki, la capital del cristianismo en Japón. Eran algunos de los supervivientes del naufragio del galeón San Felipe, que había encallado en las costas de Shikoku en octubre. ${ }^{20}$ Sin embargo, lejos de amedrentarse, este protomartirio espoleó a los frailes, que se sintieron con todo el derecho de evangelizar la antigua Cipango ${ }^{21}$ después de haber derramado su propia sangre. Además, al fin llegaban buenas noticias desde Roma: un nuevo Papa, Clemente VIII, anulaba en parte la prohibición a finales de 1600, aunque con una onerosa condición, ${ }^{22}$ por lo que pronto comenzaron a arribar predicadores..$^{23}$ Mientras tanto, los jesuitas no se quedaron ni mucho menos de brazos acusados. Como ya

18 Cabezas 1995: 92. La Nao do trato era el barco mercante que navegaba entre Macao y Nagasaki todos los años, de cuyos pingües beneficios dependía la financiación jesuita en aquella parte del mundo.

19 Fernández 1994: 524.

20 Un testigo de los hechos nos ha dejado por escrito el relato del suceso (A. G. I, Filipinas, 79, no 28).

21 Cipango, a veces Zipango, es el nombre mítico de Japón: la Isla del oro, que desde Marco Polo ha avivado la imaginación de los navegantes europeos (véase Takizawa 2012).

22 El breve de Clemente VIII levantaba el veto, pero obligaba a los religiosos a ir por la vía portuguesa de la India para pasar a Japón, lo que enfadó mucho a los españoles, que se vieron de nuevo maltratados (Gil 1991: 127).

23 Los primeros dominicos a Japón arribaron en 1602 por invitación del daimyo de Satsuma, aunque ya en 1592 el Padre Juan Cobo había visitado el país en misión diplomática, muriendo en el viaje de regreso. Aquellos dominicos de 1602 fueron cinco: fray Francisco de Morales, fray Tomás Hernández, fray Alonso de Mena, fray Tomás de Zumárraga y el hermano Juan de la Abadía (Muñoz 1965: 200). En cambio, los franciscanos habían llegado ya en 1593. habían hecho antes dominicos y franciscanos, desoyeron la instrucción papal y porfiaron en sus motivos. En 1602, el jesuita Diego García escribía al Consejo de Indias volviendo a desaconsejar la venida a Japón de otras órdenes:

Con licencia de don Francisco Tello han ido este año de aquí [las Filipinas] al Japón religiosos de las tres órdenes de Santo Domingo, San Francisco y San Agustín ${ }^{24}$ [...] Según la relación que tengo de nuestros Padres que en el Japón residen pueden ser gravísimos inconvenientes estas idas de religiosos al Japón y en especial por esta vía de Filipinas, no solo para la cristiandad de aquellas partes [...] sino también para la seguridad de este reino, que aquellos bárbaros se persuaden que los religiosos van por espías y que tras de ellos han de ir soldados, y con esto se inquietan y aun inquietan esto por acá, robando por estos mares (A. G. I., Filipinas, 84, no 102). ${ }^{25}$

A pesar de tanta insistencia, con embajadas continuas en Madrid y Roma, la Compañía no pudo expulsar a los frailes, pero se dedicaron a torpedear su trabajo o al menos de eso fueron acusados. Según se desprende de algunos documentos prohibieron a sus conversos unirse a la Confraternidad del Santo Rosario e incluso se negaron a dar confesión a quienes habían sido evangelizados por los predicadores. ${ }^{26}$

Estas denuncias son difíciles de demostrar; sin embargo, en torno al protomartirio de 1597 sí se produjeron hechos que de manera objetiva ensombrecen el papel de la Compañía. Los jesuitas no intercedieron por la vida de aquellos hombres, compartieron mesa y mantel con el juez que martirizó a los frailes y además pagaron una cantidad al verdugo, en lo que fue entendido como una propina siniestra. Los Padres se defendieron cómo pudieron, alegando impotencia en el primer caso, ignorancia en el segundo y caridad en el tercero. ${ }^{27}$ Excusas que no fueron aceptadas, más si cabe cuando los jesuitas se negaron a celebrar aquel martirio, salvo con una representación de mimos, arguyendo que los franciscanos habían entrado en Japón desobedeciendo la bula papal y, por tanto, habían muerto excomulgados:

Sabemos que Urbano VIII los declaró por mártires, con que entre católicos no se puede dudar de este punto. Por esto tuve siempre por temeridad lo que un presbítero dijo públicamente en la ciudad de Macao [...] que murieron descomulgados. Otros han dicho lo mismo. El fundamento no es más que decir que entraron en Japón contra el orden de Gregorio XIII. ${ }^{28}$

A nuestro juicio, aquellos sucesos debieron entenderse como un punto de no retorno para ambas partes. Ya no habrá

24 Juan Gil apunta que en 1602 pasaron dieciséis religiosos franciscanos, cinco dominicos y tres agustinos (Ibídem: 132).

25 No deja de ser curioso que, apenas cinco años después, un jesuita utilice el mismo argumento que según las Órdenes mendicantes la Compañía había empleado para inflamar la opinión de Hideyoshi acerca de los frailes del San Felipe (Boxer 1951: 166).

26 Para un testimonio de los juramentos que hacían los conversos por jesuitas para mantenerse lejos de otras órdenes, véase Ibídem: 418.

27 Era una práctica corriente sobornar a los verdugos para recobrar los cuerpos de los mártires. Incluso en ocasiones se compraba también la catana que se había empleado en la ejecución para venerarla como una reliquia. Por ejemplo, se sabe que se pagaron 150 escudos por la espada que mató al protomártir dominico fray Alonso Navarrete.

28 Fernández Navarrete 1676: 442. 
rivalidad, sino un odium theologicum cuya vorágine amenazaba con consecuencias imprevisibles. ${ }^{29}$ La controversia mantenida por un jesuita anónimo y fray Marcelo de Ribadeneira, a cuenta de la apertura política de Tokugawa leyasu a principios del siglo XVII, fue un claro ejemplo de que el debate no solo persistía, sino que las posturas estaban cada vez más enfrentadas. ${ }^{30}$ Un cisma que también llegó a las calles de las ciudades españolas, donde los fieles se repartían por bandos. Finalmente, gracias a la presión diplomática de la Corona española, el breve Onerosa pastoralis officii de Clemente VIII fue revocado por Paulo $V$ en 1608, en lo que fue celebrado como la reparación de una injusticia. Incansable al desaliento, la Compañía continuó pleiteando tanto en Madrid como en Roma y a punto estuvo de convencer años más tarde a un dubitativo Felipe IV, pero la decisión ya estaba tomada. En 1627, el papa Urbano VIII beatifica a los protomártires de Nagasaki ${ }^{31}$ en lo que acabó siendo la antesala de la victoria final: la constitución de 1633, que refrendaba las medidas de Paulo V, zanjándose por fin el asunto. Las Órdenes mendicantes habían ganado el pulso a los jesuitas, aunque no había nada que celebrar, pues ya por aquel entonces el cristianismo estaba prohibido en el Japón.

\section{PROPAGANDA: LA MEJOR ARMA EN TIEMPOS DE GUERRA}

La polémica entre la Compañía de Jesús y las Órdenes mendicantes no solo se disputó sobre el terciopelo de las cortes europeas, sino también en librerías, púlpitos y tertulias, donde unos y otros trataron de hacer la mejor apología de su labor misionera. En este terreno los jesuitas llevaron siempre la iniciativa, demostrando un mejor dominio de la propaganda, de la que se convirtieron en maestros indiscutibles. Uno de sus mejores logros fue la primera embajada japonesa en Europa, patrocinada por el Padre Valignano y que sin duda fue un importante golpe de efecto. Cuentan que el Papa, impresionado al ver que la palabra de Dios llegaba hasta el otro confín del mundo, se arrodilló y exclamó entre lágrimas: "Nunc dimittis servuum tuum». Además, la Compañía se encargó de publicar sistemáticamente las cartas y relaciones que se enviaban desde Japón, que aparecieron bajo el título de Litterae Annuae laponicae, que fueron todo un fenómeno editorial por el exotismo de sus noticias. No eran los únicos, ya dominicos y franciscanos habían dejado por escrito sus experiencias evangélicas, pero los jesuitas sobresalían por su sistematización rigurosa. ${ }^{32}$ Este anhelo por la publicidad de su acción apostólica se acabó convirtiendo en un mandato para el jesuita, pues se probó como un medio eficaz para el gobierno y comunicación entre misiones tan dispersas

29 No era esta la única discusión abierta entre dominicos y jesuitas en Roma. Ya desde 1582 arrancaba el debate por las Congregaciones de Auxiliis, acerca del modo de actuar de la gracia de Dios en la libertad del hombre. Los dominicos creían más en la acción de Dios, es decir, la predestinación, mientras que los jesuitas defendían la preeminencia de los actos del hombre. El papa Clemente VIII Ilegó a reconocer 68 congregaciones, pero moriría sin dictar sentencia.

30 Gil 1991: 133-135.

31 La beatificación se celebró un 15 de septiembre de 1627. Que se trataba de un gesto a favor de los frailes lo demuestra el hecho de que los hermanos legos de los jesuitas, también martirizados aquel día, no subieron a los altares hasta dos años más tarde.

32 Vega 1963: xxxiii. por el mundo ${ }^{33} y$, sobre todo, para atraer más adeptos a la causa de la Compañía, ya fuera a través del mecenazgo o con nuevas profesiones de fe.

Junto a catálogos de religiosos, capítulos de visitas, reglas, instrucciones o avisos, las letras misivas, en la variada tipología que usaron los jesuitas [...] se convertirían en una pieza fundamental del funcionamiento institucional de la orden. Con base, primero, en las reglas que elaboró Juan de Polanco en 1547 y, mas tarde, en la llamada formula o ratio scribendi, la Compañía definió con celeridad y algún rigor quiénes debían escribir cartas, cuándo, cómo y a quién, estableciendo así flujos intensos de intercambio de noticias entre súbditos y superiores, entre las provincias de la orden y entre éstas y Roma. ${ }^{34}$

Por consiguiente, no es de extrañar que los frailes vieran en esta superioridad la causa de la poderosa influencia de la Compañía en Roma. A su manera, de forma más individual y desorganizada, las Órdenes mendicantes también se interesaron por dar a conocer su labor misionera en algunos lugares, como la Nueva España, pero las noticias que venían de las Indias Orientales eran escasas. Por este motivo, en 1609 los dominicos del Asia reciben la instrucción de Agostino Galamini, Maestro General de la Orden, de dar cumplida cuenta del desarrollo de su misión. Bajo la amenaza de pecado mortal, son obligados a entregar informes de sus progresos, que en algunos casos eran completamente desconocidos. ${ }^{35}$ No era el primer intento, pues ya los dominicos de Manila, tras la celebración de un Capítulo intermedio tres años antes, habían decidido «que se juntasen con diligencia todas las cosas memorables y dignas de ponerse en historia». ${ }^{36} \mathrm{El}$ envite de los jesuitas era serio y la partida estaba lejos de ser ganada.

Sin embargo, tantas buenas resoluciones cayeron en saco roto, pues apenas llegaron escritos al Vaticano durante los años de hierro de la polémica (1597-1627). ${ }^{37}$ Cuenta Fernández Navarrete que cuando fray Juan Bautista Morales llegó a Roma en 1645 para informar sobre su misión en China, se encontró que no constaba la entrada de ningún documento de los frailes durante un largo período de años, salvo algunas notas enviadas por un agustino. ${ }^{38}$

33 En la despedida de San Francisco Javier a su amigo San Ignacio de Loyola así se lo recuerda: «resta que en este poco tiempo que desta vida nos queda, por frecuentes letras nos veamos» (Francisco Javier 1944-1945).

34 Palomo 2005: 59.

35 Acerca de las primeras misiones dominicas en el imperio de Annam (Tonkín, Cochinchina y partes de Laos y Camboya), no se sabía prácticamente nada. Más atentos a convertir pueblos que a registrar sus trabajos, fue necesario el precepto formal del Padre Galamini para que se pusiera término a tan prolongado silencio.

36 Aduarte 1640: 327.

37 Si bien los límites de la controversia son más amplios, pues ni comienza ni termina en esas fechas, creemos prudente establecer un período central de treinta años, donde el debate fue más intenso y las posiciones más escoradas. Esta etapa, que llamamos los años de hierro, daría comienzo con el protomartirio de Nagasaki (1597), cuando las Órdenes se sienten traicionadas por los jesuitas, y concluiría con la beatificación de aquellos mismos mártires (1627), verdadero jaque de los frailes a los intereses jesuíticos.

38 Fernández Navarrete 1679: 51. Esto bien podría ser una licencia literaria, pues, por ejemplo, se conserva el memorial que el sevillano Luis Sotelo, O. F., escribió al Papa desde la cárcel de Omura, poco antes de ser martirizado un 20 de enero de 1624. 
Esto no quiere decir que los frailes dieran la batalla de la propaganda por perdida, sobre todo los misioneros del Japón, que desde el inicio demostraron una clara determinación por enseñar al mundo lo que estaba sucediendo en aquellas lejanas tierras. La correspondencia entre Nagasaki y Manila es fluida, tanto que incluso se toma contacto con otras órdenes y religiosos para darles parte de la misión pastoral. En noviembre de 1617, el dominico fray Jacinto Orfanell le escribía una carta al Provincial de los agustinos, admitiendo que no se conocían de nada:

Aunque no conozco a V. R., Padre nuestro, la ocasión que se me ofrece es tal, que aunque parezca atrevimiento, no puedo dejar de dar a V. R. el parabién, y dichosas nuevas del martirio del Santo Fray Hernando de San Joseph, y hacer a V. R. partícipe del gozo, que acá tenemos, en lo que hemos visto. ${ }^{39}$

En este sentido, los dominicos destacaron sobre el resto de Órdenes, encomendándose la tarea de dar a conocer su acción evangelizadora, no solo por la competencia abierta con los jesuitas, sino también para atraer a nuevos predicadores al Japón, incluso durante las feroces persecuciones contra los cristianos:

...me acordé de esse santo convento de Barcelona, donde tomé el hábito, y juntamente me dio un remordimiento de conciencia de no escrivirles, por si alguno le diere gana de venir a ser obrero en esta viña del señor, y que no den crédito a algunos que se buelven, que con su poco espíritu dicen ahí lo que no devieran. ${ }^{40}$

Fruto de ese esfuerzo llegaron importantes historias sacras de tema japonés, como la Historia del insigne y excelente martirio de Melchor de Manzano (1629), ${ }^{41}$ la Historia eclesiástica de Jacinto Orfanell $(1633)^{42}$ y la Historia de la provincia del Santo Rosario de Diego Aduarte (1640), que, a pesar del celo con el que habían sido escritas, ${ }^{43}$ poco podían hacer frente a la colosal bibliografía jesuita, omnipresente en los cuatro rincones de Europa y disponible prácticamente en cualquier lengua moderna. ${ }^{44}$ Por consiguiente, los dominicos comprendieron pronto que solos no podrían ganar aquel envite, así que comenzaron a poner la vista más allá de las puertas del convento. Era necesario buscar el auxilio de escritores en la Corte que embellecieran los hechos con su particular estilo. En marzo de 1618, desde Japón el Padre Francisco Morales le envía al canónigo Pedro

39 «Carta al P. Fr. Alonso de Baraona, Provincial de los agustinos de Manila», en Jacinto Orfanell 1989: 125.

40 «Carta al convento de Santa Catalina, virgen y mártir de Barcelona», en Ibídem: 128.

${ }^{41}$ Este libro había sido publicado ya en Manila bajo el título de Relación verdadera (1623).

42 Sabemos que el libro se escribió mucho antes, durante los años de hierro, pues el Padre Orfanell muere como mártir en la hoguera en 1622. Sobre el proceso de escritura entre cadenas y grilletes, véanse los apuntes de Cummins en su edición al Triunfo de la fe (xxxiv).

43 En el prólogo de la Historia de Orfanell, el Padre Collado detaIla: «Por donde se verá ser historia aprobada, vista y compuesta, no solo por el padre Fray Jacinto, sino por los demás religiosos o por mejor decir, por más de 30 confesores de Cristo que estaban presos en la cárcel de Omura, pues por todos fue vista, añadida y enmendada» (Jacinto Orfanell 1633).

44 Hasta en polaco se podían leer relaciones jesuíticas acerca del Japón: Nowiny albo dzieje dwuletnie z Japonii z Chiny krajem pogańskich nowego świata to jest (Cracovia, 1611).
Fernández Navarrete ${ }^{45}$ una relación auténtica del martirio de su hermano ${ }^{46}$ con la encomienda de que se llevara a los escenarios: "Le envío de nuevo la relación auténtica del martirio. Podríais, si alguien se siente inspirado para hacerlo, mandar componer una tragedia, lo que sería muy edificante para todo el mundo». ${ }^{47}$

De hecho así fue, pues el martirio de Alonso Navarrete y sus correligionarios se dramatizó libremente en la comedia Los mártires del Japón, de atribución dudosa. ${ }^{48}$ Las obras por encargo eran una práctica corriente en la España del Siglo de Oro, sobre todo en el teatro, donde los dramaturgos se ponían al servicio del mejor postor, fuera para celebrar la genealogía de una familia ilustre o para cantar la gloria del santo fundador de alguna congregación religiosa. No solo por el dinero, sino también ocurría que a veces el poeta se adelantaba a alguna efemérides para granjearse así el favor de los homenajeados. En consecuencia, vista la altura de la ocasión y la magnitud de la polémica, qué mejor que recurrir al poeta más famoso de su tiempo.

\section{LAS RAZONES DE LOPE DE VEGA}

Uno de los primeros interrogantes que se nos plantea es intentar adivinar los motivos que impulsaron al Fénix a tomar partido en aquel odium theologicum. Una controversia de décadas que estaba enquistada desde hacía años y en el que nadie estaba dispuesto a dar un solo paso atrás. Tanto es así que amenazaba cisma, pues la hostilidad entre las Órdenes y la Compañía era palpable. Los frailes no solo echaban la culpa a los jesuitas de la persecución religiosa en el Japón, sino que incluso demandaban abiertamente la excomunión de la Compañía de Jesús: «yo argüiría con ella misma que no conviene haya en la iglesia de Dios la Compañía y aun pasaré más adelante que ni otra religión alguna de los mendicantes pusiérase a simili». ${ }^{49}$ No parecía campo abonado para poetas y mucho menos para uno como el nuestro, siempre complejo y nunca predecible.

Para empezar, de manera general Lope ni siquiera tenía una buena opinión de unos y otros, especialmente de los frailes. A pesar de ser un sacerdote desde 1614, lo cierto es que aún conservaba la mente de un seglar, llena de efervescentes tópicos anticlericales. Apenas unos meses más tarde de anunciar El triunfo de la fe, aún en aquel 1617, se burlaba de ellos en otra misiva al Duque:

Los frailes son los más discretos hombres del mundo. No van a la guerra, ni pagan millones; gozan lo mejor y danles dineros, porque dicen las mujeres que los ponen debajo [...] A la fe, señor; ellos hacen hijos y otros los crían. Perdone lo descalzo, pero yo sé [...] que se había de mudar una casa de bonetes del sitio en que estaba porque a un río venía a dar adonde se cogía agua para beber el pueblo, y

45 Para una semblanza de su biografía, véase Goñi Gaztambide1979.

46 Fray Alonso Navarrete, O. P., había muerto decapitado en compañía del agustino Fernando de San José Ayala y el catequista japonés León Tanaka el 1 de junio de 1617.

47 Pagès 1870: 189. Hemos traducido del francés al haber sido imposible localizar el original español.

48 A pesar de la última edición de Christina H. Lee (Vega 2006), que aboga por la tradicional atribución a Lope, lo cierto es que la autoría sigue en disputa con Mira de Amescua (véase Castilla Pérez 2001).

49 Willeke 1985: 96. 
decía que como se lavaba en el colegio la ropa de los tales Padres, no sé qué manchas de las camisas se deshacían en el agua y de aquella andaban preñadas todas las mujeres que la bebían. ${ }^{50}$

Sin duda, no creemos que repitiera esos mismos comentarios en público, están hechos al calor de la correspondencia privada con el Duque, pero se trata de un claro testimonio de su manera de pensar. Hecha esta referencia, no podemos dejar de advertir que al final del párrafo se retracta un tanto y salva a la mayoría de sus chanzas: "Esto es cuanto a los malos. Santos hay muchos, y lo serán esos dos, y otros, a más no poder $"{ }^{51}$ Al fin y al cabo, privada o no, nunca se sabe quién podría leer aquella carta: «porque puede dañar mucho cualquier palabra escrita, y no ha habido en el mundo secreto revelado ni suceso adverso en que no haya intervenido hábito». ${ }^{52}$

No obstante, si volvemos la vista al rincón de la Compañía, tampoco salen bien parados. A finales de diciembre aún en 1617-, Lope retomaba la pluma para escribir a su mecenas. En aquella ocasión, entre otros asuntos, aludía a la agresividad de ciertos jesuitas que andaban adquiriendo las propiedades colindantes a la suya. Nuestro poeta era un orgulloso propietario que había conseguido comprar su casilla con el dinero ganado con su oficio de escritor (algo inaudito para la época), por lo que no se le pasaba por la cabeza vender, aunque temiera por su suerte, pues reconocía que el brazo de la Compañía era poderoso:

Hasta agora no nos han quitado la casa estos padres, que las de los lados son las que más han menester y, aunque entraron con cohetes, no quieren que sea a fuego y sangre. Poco a poco se irán extendiendo; que las religiones, como no se mueren, tienen con el tiempo estrecha correspondencia y alcanzan donde quieren. Finalmente, cuando me quiten mi casilla, mi quietud, mi güertecillo y estudio, me queda vuestra excelencia, que este bien no me lo puede quitar ni el poder, ni el tiempo, ni la codicia, ni la muerte..$^{53}$

Hecha esta salvedad, era pública y notoria la cordialidad que Lope tenía por aquel entonces con miembros eminentes del clero, como por ejemplo el mínimo fray Lucas de Montoya o el trinitario fray Hortensio F. Paravicino, dentro de las Órdenes mendicantes, y los jesuitas Juan Luis de la Cerda o Juan de Mariana, en el otro lado del tablero. Al fin y al cabo, no podemos obviar el hecho de que se había educado de niño en los colegios de la Compañía. Además, su amistad con estos ilustres Padres fue sincera, más aun durante aquellos años de la Spongia, cuando los tres tuvieron que hacer frente común para defenderse de los ataques de Torres Rámila. ${ }^{54}$ De hecho, a este último -el Padre Mariana- le dedica el prólogo de El triunfo de la fe en un claro intento de poner una vela a Dios y otra al diablo.

Al mismo tiempo, también es verdad que la retórica franciscana tuvo una influencia patente en sus obras religiosas, especialmente en el Isidro (1598), reverberando

\footnotetext{
50 Vega 2008: 390-391.

51 Ibídem: 391.

52 Ibídem: 361.

53 Ibídem: 395. Los jesuitas no consiguieron que vendiera. Lope pasaría el resto de sus días en su casilla de la calle Francos.

54 González-Barrera 2011: 12-15.
}

luego en un plano más íntimo, no solo por el hecho de que fuera su deseo ser enterrado en hábito franciscano, que era una práctica común en el siglo XVII, sino porque mantenía un trato estrecho con los frailes, a cuya Orden Tercera pertenecía desde 1611. Por lo tanto, en materia de afectos o sentimientos sería temerario que nos pusiéramos aquí a hacer juicios de valor sobre las preferencias personales del Fénix, pero es razonable creer, al menos, que la controversia entre frailes y padres a cuenta del Japón no sería del todo ajena a su conocimiento, aunque, claro está, distante a sus verdaderos intereses. No consta que Lope tuviera intención alguna de participar en aquella diatriba más allá de su simple faceta como historiador sacro.

El compromiso para escribir aquella «historia de unos mártires» tendría buena parte de explicación en la profunda crisis espiritual que sufrió Lope a partir de 16101611, agravada por las muertes prematuras de su hijo Carlos Félix (1612) y su esposa Juana de Guardo (1613), que desembocará al año siguiente en su ordenación como sacerdote. Una toma de hábitos que dio comienzo a una serie de obras religiosas donde Lope deja por escrito el más hermoso arrepentimiento por sus pecados. Una de ellas será El triunfo de la fe, obra a la que se encomienda con lágrimas en los ojos, pues, a su juicio, el mejor ejemplo cristiano de los mártires pone en evidencia su verdadera falta de devoción:

...certifico a los que las leyeren, confesando mi ignorancia, que donde faltare la pluma suplirán las lágrimas, sin las cuales no me ha sido posible dictarle esta piadosa historia, ánimo de los que padecen por Dios y afrenta de los que con tal descuido esperamos el incierto límite de nuestra vida. ${ }^{55}$

Por otra parte, quizás por alarde de vanidad o simple excusa ante su amigo jesuita, Lope intenta justificarse por su nombramiento de notario apostólico, cargo honorífico por aquel entonces, pero que se encargaba antiguamente de recibir los documentos relacionados con la historia de la Iglesia y dar fe de su autenticidad. Al menos esa parece que fue su intención, pues no solo en el prólogo, sino también en la dedicatoria al cardenal-arzobispo de Toledo habla de «fragmento de Historia sacra»:

Costumbre fue antigua suya, como advirtió muy bien el Obispo de Tarazona, [...] en su docta Historia de Inglaterra, para escribir las persecuciones de los tiranos y los gloriosos triunfos de los mártires, tener notarios, y que estos fuesen personas fidedignas; yo lo soy apostólico. ${ }^{56}$

Un motivo diferente, aunque relacionado con los anteriores, sería que aquel encargo llegaba en el momento justo, pues podía emplear aquel martirologio como contestación pública a los dardos de Torres Rámila, ${ }^{57}$ ya que ocuparse de menesteres tan piadosos reparaba en parte el daño causado en la Villa y Corte, que había quedado un tanto polarizada con la polémica. ${ }^{58}$ De paso además seguía

\footnotetext{
55 Vega 1963: 16.

56 Ibídem: 9-10.
}

57 Uno de los ataques más feroces que se puede leer en la Spongia viene a cuenta de su moral disoluta: «No es apropiado que el que refrena a la juventud lujuriosa y depravada con la Ética y la Política sea siempre un descarado» (González-Barrera 2011: 189).

58 Las críticas de la Spongia tuvieron su público, como se admite en la Expostulatio: «Estas tonterías en folios [la Spongia], divulgadas 
fomentando su imagen de poeta culto, que tanto le ocupó y preocupó a lo largo de su vida.

La tinta de la Spongia aún estaba fresca. El Triunfo era su primer libro tras la tormenta del opúsculo turriano y el Fénix no dejará pasar la ocasión para ajustar cuentas con Torres Rámila en el prólogo. ${ }^{59}$ Sin olvidar el hecho de que convertirse en historiador de las Órdenes mendicantes le ponía frente por frente con otro de sus enemigos en la guerra de la Spongia: Cristóbal Suárez de Figueroa (15711644), ${ }^{60}$ que recientemente había traducido una historia de la Compañía de Jesús: la Historia y Anal relación de las cosas que hicieron los Padres de la Compañía de Jesús (1614). Cuanto menos se trataba de una felicísima coincidencia y, por supuesto, competir con su rival en materia tan culta como la historiografía sacra tuvo ser un acicate irresistible para él.

Una cuarta y última razón habría que buscarla en la propia curiosidad del autor. Japón era una tierra fabulosa, remota y desconocida para una amplísima mayoría de los españoles del siglo XVII. Más leyenda que realidad para muchos, cualquier novedad era recibida con estupor y asombro. Así, a los ojos del pueblo, poder llevar a la imprenta hechos tan recientes a la par que grandiosos para el ejemplo cristiano convertían al Fénix en un cronista de mundos lejanos:

No será necesaria la memoria de sus hazañas, como de aquellas que por ser tan frescas en el otro polo, aún no han llegado al nuestro, que puesto que los ejemplos de la pasada memoria [...] tanto traigan de autoridad para probar y deleite para oír; no menos confirman la verdad que se prueba los que con imitarlos después de tanta distancia sienten lo mismo. ${ }^{61}$

En definitiva, el encargo de componer una historia de los mártires del Japón era un caramelo demasiado goloso. A Lope nunca pareció interesarle aquel odium theologicum y muy posiblemente escribiera aquel librito de forma altruista, pero la recompensa en términos de paz espiritual, prestigio y revancha tuvieron que ser satisfacción más que suficiente.

\section{LOPE DE VEGA Y LOS DOMINICOS: LA CAMARILLA DE SAN ESTEBAN}

Una vez expuestas las posibles motivaciones del poeta madrileño, habría que poner la atención en el otro lado de la mesa: la Orden de Santo Domingo. El Triunfo fue un encargo orquestado, conducido y preparado en las islas Filipinas. Como el propio Lope reconocía en las páginas del prólogo: «escribo los martirios no testigo de vista, que no fue mi dicha tanta, pero por relaciones de algunos Padres, que me las enviaron desde Manila a efecto que en el estilo con que he nacido las publicase». ${ }^{62}$

en medio de una muchedumbre cortesana tan diversa, hallaron proscriptores allá, patronos acá, cuyas opiniones tan distintas y contradictorias entre sí condenaron en parte los vicios de aquél, y en parte elogiaron el exultante entusiasmo de su estilo, sin consultarle antes al pregonero» (Ibídem: 287).

59 No estamos de acuerdo con J. S. Cummins cuando dice que el tono de la crítica es sereno (xxxviii). No puede ser mesurado llamar a alguien "onagro silenio» o desear que acabe desollado como Marsias (Vega 1963: 9).

60 Cristóbal Suárez de Figueroa aparece caricaturizado bajo el personaje de Satirión en el Sueño jocoso de la Expostulatio (GonzálezBarrera 2011: 277-289).

61 Vega 1963: 14

62 Ibídem: 16.
En un primer momento aquella referencia a unos Padres llevó a la confusión, pues se pensó que se trataba de jesuitas, aunque pronto fue una hipótesis completamente descartada a la vista de las pruebas. Como ya demostrara J. S. Cummins en su excelente introducción al Triunfo, las fuentes primarias son una carta-relación que fray Jacinto Orfanell ${ }^{63}$ había enviado desde Japón a Manila junto a la cabeza del mártir Juan Quinzayemon, ${ }^{64}$ y acaso material de la Historia eclesiástica, libro que había redactado el propio Padre Orfanell, pero que no se publicaría hasta muchos años más tarde (Madrid, 1633). ${ }^{65}$

El 28 de marzo de 1615, el Padre Orfanell escribía a fray Baltasar Fort, antiguo vicario provincial de la Orden en Manila, para relatarle la persecución religiosa que estaba sucediendo en el Japón desde los últimos meses del año anterior. ${ }^{66}$ Valenciano como Orfanell, aunque prohijado a la Provincia de Aragón a posteriori, en realidad el Padre Fort había tomado los hábitos en Salamanca, como tantos otros dominicos de las Filipinas, pues en el archipiélago existía un importante núcleo de misioneros que procedían del convento de San Esteban. ${ }^{67}$

Eran viejos conocidos, quizás incluso amigos. De hecho, no hacía ni seis meses que se habían separado. Ambos habían compartido misión en el Japón hasta aquel 6 de noviembre de 1614, cuando fueron expulsados todos los misioneros por orden del shogun Tokugawa. En Fukuda -cerca de Nagasakicuatro dominicos esperaban para embarcarse para Manila: fray Domingo Valderrama, ${ }^{68}$ fray Baltasar Fort, fray Francisco de Morales $^{69}$ y el propio fray Orfanell. Sin embargo, solo

63 Jacinto Orfanell (1578-1622): nacido en Jana (Castellón), profesó en el convento de Santa Catalina de Barcelona en 1601. A las islas Filipinas Ilegaría en 1607 de la mano de fray Diego Aduarte, al que conoce en Valladolid y le convence de unirse a la provincia del Santo Rosario. Murió quemado vivo un 10 de septiembre de 1622 . Beatificado por Pío IX en 1867.

64 El verdadero nombre era Takaya Kyuzayemon (高屋·九左衛門). En noviembre de 1614 había muerto decapitado junto a su hermano Shobioye, después de sufrir ambos horribles torturas para intentar que renegaran de su fe.

65 José Delgado, O. P., y Manuel González, O. P., editores de la obra de Orfanell, descartan esta hipótesis de J. S. Cummins ( $\mathrm{xl}$ ) en base a una reconstrucción del traslado -hoy perdido- con otras cartas del beato (157-160).

${ }_{66}$ El autógrafo se conserva en el Archivo de los Dominicos de Manila (APSR, Ms. 19, ff. 346r-349v). Ya en época contemporánea, véase Carta al P. Baltasar Fort escrita desde Nagasaki, 28 de marzo, 1615 de fray Jacinto Orfanell publicada en 1922 en la revista Misiones dominicanas 5: 389 y en 1923, Misiones dominicanas 6: 26-27, 58-59, 89-90, 123-124, 217-218, 251-252. Posteriormente, en Muñoz, Honorio 1967: 124-138; y luego en edición moderna, anotada y completa dentro del volumen Jacinto Orfanell 1989: 142-156.

67 «A fines del siglo XVI ya había en Filipinas más de un centenar de dominicos y de ellos según datos del Archivo General de Indias unos treinta eran del convento de San Esteban» (Espinel 1995: 168).

68 Domingo Valderrama (1587-?): natural de la villa de Osuna (Sevilla), poco sabemos de este fraile salvo que llegó a Japón en 1611 junto a fray Alonso Navarrete y que regresó a Manila con el decreto de expulsión. Lector y predicador del convento de San Pablo, tenemos noticias de que al menos en 1628 estaba en España (Rodríguez Rodríguez y Álvarez Fernández 1993: 193).

69 Francisco de Morales (1567-1622): de origen madrileño, se formó en el convento de San Pablo de Valladolid. Lector de filosofía en el convento de San Esteban de Salamanca, desde donde partiría para las islas Filipinas en 1598. Elegido primer Vicario provincial del Japón, murió en la hoguera un 10 de septiembre a las afueras de Nagasaki. Beatificado por Pío IX en 1867. 
los dos primeros tenían intención real de marcharse. Los dos últimos habían concertado volverse auxiliados por los franciscanos, que los recogerían a pocas leguas de la costa. Los Padres Fort y Orfanell nunca más se volverían a ver:

De los quatro que dixe que llegamos a Fucunda, solo dos llevávamos intento que se embarcassen. Lo uno por cumplir con los ministros de la justicia [Valderrama] y lo otro, porque aún no sabían bien lengua los dos [Fort]. Los dos que nunca tuvimos intento de irnos de Japón sino embarcarnos solo por cumplimiento, que fuimos el P. Fr. Francisco de Morales y io, teníamos conçertado con los clérigos y Padres de $\mathrm{S}$. Francisco embarcaçiones de Christianos que nos viniessen a cojer, como lo hizieron dos o tres leguas a la mar, donde, como pudimos, cada uno en su embarcación nos desapareçimos. ${ }^{70}$

No habían sido los únicos. Amparados en el anonimato que les daba no estar en las listas del bakufu, otros cinco dominicos ya andaban escondidos por chozas, caminos y montes: a saber, fray Tomás de Zumárraga, ${ }^{71}$ Vicario provincial, fray José Salvanés de San Jacinto, ${ }^{72}$ fray Juan de Rueda, ${ }^{73}$ fray Alonso de Mena ${ }^{74}$ y fray Alonso Navarrete. ${ }^{75}$ Todos ellos morirían como mártires.

Como ya hemos señalado anteriormente, los dominicos de Filipinas tenían orden capitular primero (1606) y orden general después (1609) de dejar testimonio de los hechos de su apostolado. Había mucho en juego. Una responsabilidad que está particularmente latente en la correspondencia del Padre Orfanell. No solo se ocupó con esmero de escribir los sucesos de la cristiandad del Japón, sino que se preocupó de dejar copias o traslados de sus relaciones, para que se pudieran difundir por los cuatro rincones. En una carta a Fray Diego Carlos, Vicario provincial de Cagayán demostraba una plena conciencia de su tarea:

Por avérmelo mandado la obediencia hize esta relación para embiar a Manila, y quize embiarla también a Vuestras Reverencias. Va todo lo que fideliter pude saber, dexando otras muchas cosas, que no son tan ciertas. El martirio de los santos fray Alonso Navarrete y fray Hernando de Ayala, aunque ya Vuestras Reverencias le tienen ay impreso

70 «Relación de las cosas sucedidas en esta persecución de Japón. Japón, 25 octubre 1619», en Jacinto Orfanell 1989: 176.

71 Tomás de Zumárraga (1577-1622): alavés de nacimiento, en religión fue hijo del convento de Vitoria. De allí a las Filipinas en 1601 , donde solo permanecería apenas un año, pues saldría para Japón a siguiente. Murió en la hoguera en Omura. Beatificado por Pío IX en 1867.

72 José Salvanés de San Jacinto (? -1622): madrileño, profesó en el convento de Santo Domingo de Ocaña (Toledo). Misionero en México y después en Japón fue martirizado a fuego lento un 10 de septiembre en Nagasaki. Beatificado por Pío IX en 1867.

73 Juan de Rueda (?-1623): burgalés, en religión fue hijo del convento de San Pablo de Valladolid. En 1603 partiría para las Filipinas, saliendo para Japón al año siguiente. Muere decapitado en Okinawa.

74 Alonso de Mena (1578-1622): nacido en Logroño, tomó los hábitos en el convento de San Esteban de Salamanca. En 1602 llegaba a Manila y desde allí directamente al Japón, donde misionó hasta que fue quemado vivo un 10 de septiembre en Nagasaki. Beatificado por Pío IX en 1867.

75 Alonso Navarrete (1571-1617): natural de Logroño, se formó en el convento de San Pablo de Valladolid. Hermano del canónigo Fernández Navarrete (véase n. 43) y primo hermano de Alonso de Mena (véase nota precedente). Hasta en dos ocasiones distintas estuvo de misionero en Filipinas antes de pasar a Japón en 1611. Murió degollado el 1 de junio de 1617. Beatificado por Pío IX en 1867. y muy bueno, por no cortar el hilo a la relación y que se tenga todo junto, le trasladé aquí casi ad pedem literae. ${ }^{76}$

Tanto es así, que no solo se carteaba con sus correligionarios de las Filipinas, sino que también establecía contactos con España, dando fe pública de sus acciones y animando a otros a seguir la misión evangélica, aun sabiendo la extrema dificultad de comunicar dos tierras tan distantes en el mapa: «No seré largo porque me quita la gana de escrivir ver la incertidumbre que ay llegar esta carta en camino tan largo ${ }^{77}$ En esta carta al convento de Santa Catalina de Barcelona, antes referida, hay una curiosa noticia sobre la misión japonesa. A pesar de tantas amenazas, peligros y estrecheces, sin dinero ni vestido "aunque se muera», destaca de repente la familiaridad entre los frailes, describiendo un ambiente de franca compaña que más sonaba a camarilla de soldados que a grupo de religiosos:

En lo demás ay mucha hermandad y llaneza: todos nos tratamos de Reverencias, hasta el mismo Provincial le llamamos Reverencia, y desde que entré en esta Provincia no e tomado en la boca Paternidad, ni en el discurso desta carta e acertado a dezirla que agora repare. Vs. Rs. me perdonen. ${ }^{78}$

De aquel círculo de camaradería, por otra parte necesaria, pues la persecución contra los cristianos era terrible, surgió la ocurrencia de enviar una relación a España. No para que fuese llevada directamente a la imprenta, como ya se venía haciendo, sino para que sirviera de inspiración a algún poeta: "a efecto que en el estilo con que he nacido las publicase ${ }^{79}$ dijo Lope en una frase que más suena a petición leída o escuchada de otros que a justificación propia.

La carta de Orfanell, escrita a modo de relación, no estaba dirigida a un cualquiera, o mejor dicho, no había sido elegido al azar. Posibles amistades aparte, aunque ya no ostentara ningún cargo, el Padre Fort era un dominico respetado que había contribuido a la fundación del Colegio universitario de Santo Tomás, ${ }^{80}$ tenía el timbre de haber misionado en Japón y su abolengo eclesiástico no podía ser más alto, pues era hijo religioso del convento de San Esteban, uno de los centros más poderosos de la Orden en Europa, por cuyos claustros habían pasado figuras ilustres como Francisco de Vitoria, ${ }^{81}$ Melchor Cano ${ }^{82}$ y Domingo de

76 «Carta al P. Vicario provincial y religiosos dominicos de Cagayán (Filipinas)», en Jacinto Orfanell 1989: 136.

77 «Carta al convento de Santa Catalina, virgen y mártir de Barcelona», en Ibídem: 128.

78 Ibídem: 132.

79 Ibídem: 16.

80 El padre Fort firmaba el acta de erección un 28 de abril de 1611 en Manila ante el escribano del Rey, aunque el Capítulo Provincial de la Orden no la aprobaría hasta el año siguiente, ya con el padre Miguel Martín de San Jacinto como nuevo Vicario.

81 Francisco de Vitoria (1483-1546): uno de los grandes pensadores del siglo XVI. Sus ideas sentaron las bases del Derecho Internacional. Si bien había tomado los hábitos en el convento de Burgos, residió en San Esteban durante los veinte años que ocupó la cátedra de prima de Teología en Salamanca, es decir, hasta su muerte.

82 Melchor Cano (1509-1560): discípulo de Francisco de Vitoria, fue uno de los teólogos elegidos por Carlos $V$ para representar a España en el Concilio de Trento. Hijo religioso de San Esteban, llegó a ser su prior y Provincial de Castilla. Consultado por Felipe II, defendió la guerra justa contra el Papa. Su obra principal se titula De los 
Soto, ${ }^{83}$ y que desde tiempo inmemorial había copado las cátedras de Teología de la Universidad de Salamanca. La influencia de San Esteban alcanzaba también a la Corte, no solo por el prestigio de sus teólogos sino también por la cantidad de nobles segundones que habían sido enviados a profesar allí. ${ }^{84}$ Prueba reciente de su peso en la Corte había llegado en 1608, cuando el duque de Lerma fundó una cátedra de Vísperas por presentación para los teólogos de San Esteban, que amenazaban con dejar la Universidad de Salamanca, hastiados del trabajo y disgustos que acompañaban las oposiciones. ${ }^{85}$ En definitiva, si se trataba de buscar un poeta cortesano para aquella «historia de unos mártires», no había mejor tarjeta de presentación que una recomendación desde San Esteban.

Ya con cierta fama entre los suyos, ${ }^{86}$ ejerciendo como cronista de la Orden en el Japón, ${ }^{87}$ responsabilidad que seguiría cumpliendo incluso en la cárcel, ${ }^{88}$ el Padre Orfanell escribió aquella relación animado por otros, el Padre Fort cuanto menos, como bien señalan José Delgado, O. P., y Manuel González, O. P., editores modernos del epistolario del beato:

Y termina diciendo: "lo que V. R. desea saber en sustancia aquí va todo"; lo que parece dar a entender que esta carta-relación responde a una petición o deseo manifestado por el P. Fort al P. Orfanell, quizás en Japón mismo, o al despedirse el 6 de noviembre anterior, o por carta desde Manila. ${ }^{89}$

Sin embargo, sucederá un contratiempo imprevisto. A pesar de haber preparado una copia o traslado de la carta, Orfanell se entera demasiado tarde de que el Padre Fort no estará en Manila para recibir la misiva -y la cabeza del mártir-, por lo que cambia de planes en el último momento: «pero después de escrito me dixeron que V. R. no estaría en Manila quando estas cartas lleguen, y assí remitto el

lugares teológicos (1563), una reflexión sobre las fuentes válidas para la Teología.

83 Domingo de Soto (1494-1560): confesor del emperador Carlos V, en sus comentarios a la Física de Aristóteles descubrió la teoría de la caída de los cuerpos sesenta años antes que Galileo. Como ya sucediera con Francisco de Vitoria, el Padre Soto había profesado en Burgos, pero vivió en San Esteban mientras fue catedrático de Vísperas, primero, y de Teología, después, en Salamanca. Llegó a ser prior del convento.

${ }_{84}$ Valga como simple ejemplo el caso del cardenal Juan Álvarez de Toledo, hijo del II Duque de Alba y por tanto tío del Gran Duque (Espinel 1995: 107-108).

85 No sería la única: años más tarde Felipe IV funda otra cátedra de Teología por presentación destinada a los frailes de San Esteban.

86 «Esta relación [la suya, del 25 de marzo de 1615] de los santos mártires va para que $V$. R. se entretenga, mientras llega la que envió para V. R. el P. Fr. Jacinto Orfanell, que es la relación más cierta y de mejor estilo» (Muñoz 1963: 61, n. 14).

87 En un primer momento de manera oficiosa, movido por su gusto por la escritura y el aliento de sus hermanos dominicos, pero a partir del Capítulo provincial de 1619 de forma oficial, pues recibe el mandato de escribir una Historia de la Provincia.

88 «Venido a esta cárcel supe de los Padres, y demás presos de algunos santos mártires que yo no avía sabido, los quales van añadidos en este borrador, que fue el segundo que saqué, y enmendadas algunas cosas, quisiera trasladarle, o hazerle trasladar para que fuera limpio; pero no me atreví, por el peligro que corría no le tomassen las guardas» («Carta al P. Fr. Francisco Hurtado, O. P. Cárcel de Omura, 20 agosto 1621», en Jacinto Orfanell 1989: 137).

89 Ibídem: 83. traslado al Padre prior de Manila, para que le enbíen a España.$^{90}$ Parece ser que la idea original era remitir la copia a la provincia de Aragón, ${ }^{91}$ de donde procedían ambos, pero a la luz de los acontecimientos está claro que sus derroteros fueron otros: "Otro traslado va también para V. R. deste borrador, en el qual de propósito hago mençión de los mártyres de los años passados con intento de que senbiasse a nuestra provincia o, la sustancia del para que sepan de las maravillas que el Señor obra por acá». ${ }^{92}$

El camino desde las Filipinas hasta España es quizás la parte más turbia de nuestro relato. No sabemos nada acerca de la suerte de la carta, salvo, claro está, que llegó a su destino. A pesar de que recuperamos su pista gracias a las noticias de Lope, lo cierto es que desde la primavera de 1615 -Nagasaki- hasta el verano de 1617 -Madrid-, el rastro se pierde. No obstante, aun siendo solo una conjetura, nos parece plausible la hipótesis lanzada en su día por Delgado y González. ${ }^{93}$ El Padre Juan de Leiva, ${ }^{94}$ prior en Manila por aquel entonces, cumplió los deseos del Padre Orfanell y mandó la carta a España por el único camino posible: la Nueva España. En el galeón de Manila pudo ser llevada por el Padre Anastasio Moya cuando partió de las islas en 1616, tras ser nombrado Vicario de la casa de Nuestra Señora de la Guía de México. Desde allí hasta la Península cabe la posibilidad de que el mensajero fuera fray Diego Aduarte, cuando regresó desde México a finales de aquel 1616. No dejaría de ser irónico, pues se trata de la misma persona que había convencido al Padre Orfanell para que misionara en el Japón.

Una vez que la carta-relación llega a España, más en concreto a Madrid, quedaría por dilucidar quién fue el último intermediario entre Lope y la Orden de Predicadores, esto es, quién encargó el libro en persona. Hasta hoy no se sabía prácticamente nada. Solo contábamos con la teoría de J. S. Cummins, ${ }^{95}$ que en su edición apuesta por el canónigo Pedro Fernández Navarrete, hermano de fray Alonso, como muñidor en la Corte por mediación de fray Francisco de Morales, pero lo cierto es que la única evidencia que aporta el investigador es esa: que era hermano y primo de dominicos. ${ }^{96}$ Demasiado poco, a nuestro modesto entender. Por otra parte, Delgado y González admiten como posible su intervención, pero prefieren desviar el objetivo hacia los propios misioneros, fray Navarrete y fray Mena, que habrían hecho la labor de puente entre Asia y Europa, y no tanto sobre la figura de fray Morales. ${ }^{97}$ Cierto es que tal conexión existía, por la correspondencia que se conserva del triángulo canónigo-Mena-Morales, de la que hemos dado prueba en

90 «Breve relación de los mártires de Japón. Nagasaki, 28 marzo 1615», en Ibídem: 156.

91 La Orden de Predicadores dividía entonces -y ahora- el territorio nacional español en tres provincias: España, Aragón y la Bética.

92 Ibídem: 156.

93 Ibídem: 85.

94 Juan de Leiva (?-1620): riojano de nacimiento, profesó en el convento de Nuestra Señora de Atocha de Madrid y fue colegial de Alcalá. Era prior de Santo Domingo de Manila desde 1614. Poco se conoce de su biografía, pero para saber algo más, véase Ocio y Neira 2000: 100.

95 Hasta la fecha no ha habido ninguna otra aproximación crítica a la génesis de El triunfo, salvo quizás la de Pierre Civil (2005) y Antonio Carreño (2013), pero ambos evitan pronunciarse sobre la gestación de la obra.

96 Vega 1963: xxxvi.

97 Jacinto Orfanell 1989: 85-86. 
páginas anteriores, pero de nuevo nos encontramos con simples conjeturas sin más apoyos que la intuición.

Aun reconociendo que son teorías razonables, que el Padre Morales le propusiera al canónigo que buscara a alguien para componer una tragedia en honor de fray Alonso, ${ }^{98}$ no significa necesariamente que también participara en la preparación del Triunfo. El martirio de su hermano sí era un suceso doloroso, familiar y privado que le atañía directamente. Si el Padre Morales ya hubiera implicado al canónigo el año anterior, seguro que el tono de la misiva hubiera sido muy diferente y desde luego hubiéramos podido leer alguna mención a la experiencia pasada, el Triunfo o incluso a Lope, aunque solo fuera como disculpa por molestarle de nuevo:

Le envío de nuevo la relación auténtica del martirio. Podríais, si alguien se siente inspirado para hacerlo, mandar componer una tragedia, lo que sería muy edificante para todo el mundo. También le envío un poco de sangre del mártir y la espada con la que fue decapitado por Jesucristo. ${ }^{99}$

Asimismo, por el mismo motivo el Padre Mena le envía otra relación a su primo, pero sin otro encargo, salvo que la lea: "Con esta carta le envío a V. R. una relación para que la lea en busca de consuelo y se la comunique a sus hermanos y a sus padres». ${ }^{100} \mathrm{Si}$ en tamaña ocasión, como era un martirio familiar, no se atrevía a pedirle el favor a su primo, mucho menos pensamos que lo habría hecho para el padre Orfanell.

Por todas estas razones creemos que habría que poner la atención en otro lugar y personas. Pero no habría que irse demasiado lejos, pues la respuesta la hallamos en las páginas de la referida Expostulatio Spongiae, publicada en 1618, como el Triunfo. Dentro de los «Elogios de ilustrísimos varones en defensa de Lope de Vega Carpio», sacados en su mayoría de los preliminares de sus obras, nos tropezamos en cambio con algunos textos inéditos, como el fragmento titulado: «Carta de Juan Bautista Elgueta, profesor de Teología, a Vega». ${ }^{101}$ Reproducimos a continuación de forma integral:

He visto, docto Vega, tu librito sobre El triunfo de la fe, lo he leído y me ha gustado de manera extraordinaria. En verdad, la claridad de contenido y la exquisitez del discurso captaron mi ánimo de tal modo, que apenas si he podido apartarme de su lectura. Alabo mucho tu obra. La sociedad estará siempre en deuda contigo por este título. Hablaría aquí de la elegancia de tu pluma mientras te reprimes con una concisión histórica, como el Menelao homérico, o arrojas tus sentencias eruditas a través de laconismos, si la falta de tiempo no me obligase más a autosquedíacen que a disertar. ${ }^{102}$

98 La manera en la que fray Navarrete se entregó al martirio estuvo envuelta en la polémica hasta el siglo XIX, a pesar de su beatificación: «Crétincau Joly, apasionado historiador de los Jesuitas, llama al beato Alfonso Navarrete fanático y aventurero, cuyo celo indiscreto mereció el desprecio y la burla de todos. La Iglesia le ha decretado solemnemente los honores de Beato, le ha puesto en los altares; luego el fanático, aventurero, indiscreto, calumniador y hasta blasfemo, es Crétincau Joly» (Martínez Vigil 1884: 151).

99 Pagès 1870: 189. Volvemos a traducir del francés al haber sido imposible localizar el original español.

100 Ibídem: 187. Traducimos del francés.

101 IOHANNIS BAPTISTAE Elgueta Theologiae professoris epistola ad Vegam (González-Barrera 2011: 162).

102 Ibídem: 163.
Una felicitación que cuanto menos sorprende por su premura. La tasa del Triunfo es del 29 de enero de 1618, por lo que no se pudo comercializar hasta inicios de febrero. En el caso de la Expostulatio no se conoce la fecha de publicación, pero uno de los prólogos está firmado un 4 de junio, por lo que su divulgación tuvo rondar el principio del verano. ${ }^{103} \mathrm{En}$ suma, cuatro meses en el mejor de los casos para buscar, comprar y leer el Triunfo, y enviar, recibir y publicar esta carta. Por ende, un intervalo de tiempo tan corto que situaría a ambos personajes en un espacio próximo.

Otro detalle no menor radicaría en el hecho de que mantuviera correspondencia privada con Lope. Dadas las dificultades de la época, lo frecuente era un intercambio epistolar con conocidos, fueran amigos o enemigos, por lo que no cabe pensar que fuera la simple enhorabuena de un admirador desconocido. El tono mismo lo delata. Habrá que esperar varios siglos para encontrar un fenómeno semejante. Por consiguiente, podemos deducir sin temor que el Padre Elgueta y Lope ya se conocían.

Pero lo más relevante llega cuando descubrimos quién era este profesor de Teología que se carteaba con poetas y que había corrido a felicitar a Lope por la publicación del Triunfo. Pues se trata del Padre Juan Bautista Elgueta (? - 1628), ${ }^{104}$ fraile dominico, hijo religioso del convento de San Esteban de Salamanca, cuyos lazos con la provincia del Santo Rosario quedan más que probados por el hecho de que tiempo después estaba de ministro doctrinero en Pangasinan (Filipinas) y desde 1625 impartiendo clases en el Colegio universitario de Santo Tomás de Manila. En 1627 participaría en la primera misión católica a Taiwán, ${ }^{105}$ pero enfermaría al poco, regresando a Filipinas para morir al año siguiente.

Como ya hemos advertido, los plazos exiguos de la carta determinan un escenario donde el dominico aún estaba en España por aquel 1618, probablemente en Salamanca. Parece imposible que el Padre Elgueta le hubiera escrito desde Manila o cualquier otro lugar de las Indias. Solamente el libro hubiera tardado ya más de cuatro meses en llegar a las islas Filipinas. Su vínculo con las misiones dominicas en el Asia, de las que acabaría formando parte, tampoco puede ser desdeñado. No podemos saber si el trato con el poeta madrileño empezó a raíz de este libro o era una vieja amistad, ${ }^{106}$ pero poco importa. Lo cierto es que cuando los escritos del Padre Orfanell llegan a España, el encargo tuvo que partir del influyente convento salmantino de San Esteban y, más concretamente, del Padre Elgueta, quien

103 En el Siglo de Oro era costumbre escribir los preliminares -esto es, prólogos, dedicatorias y poemas laudatorios- al final, cuando el libro ya estaba listo para ser publicado.

104 La mayoría de estos datos biográficos están sacados de Ocio y Neira 2000: 135.

105 Tsai 2009: 28.

106 En la Expostulatio se puede leer una misteriosa alusión a la Universidad de Salamanca, pero no existe hoy ningún dato documental que vincule a esta con Lope: «A vosotras os pongo por testigo, célebres universidades de toda España, que honrasteis a vuestro alumno [Lope] con honores públicos a plena luz del día y de la vista de todo el mundo y le ennoblecisteis con tantos homenajes honorarios. ¿Os acordáis, aulas salmantinas, de que vuestros pupitres y cátedras habían crujido numerosas veces con los aplausos del auditorio, con las voces unánimes de las felicitaciones y de que en tantas ocasiones ha saltado de alegría vuestra Atenea?» (González-Barrera 2011: 223). 
habría sido la persona que se había puesto en contacto con Lope. Solo así se explicaría la celeridad de aquella reseña literaria, es decir, el sumo interés y gratitud que demuestra por El triunfo: «Alabo mucho tu obra. La sociedad estará siempre en deuda contigo por este título». ${ }^{107} \mathrm{El}$ fraile dominico estaba al tanto de la existencia del volumen porque él mismo había sido partícipe del proceso, de ahí que pudiera leerlo prácticamente recién salido de imprenta. El sentimiento que demuestra por la obra -y solo por esta al parecer- evidencia una palpable predilección personal por El triunfo de la fe. El libro y no el autor es el protagonista de la carta, que más parece una elegante nota de gratitud que el testimonio de un incondicional.

En conclusión, todo apunta a que este misionero dominico fue el intermediario entre la Orden y Lope, porque, de lo contrario, habría dejar la explicación en manos de una gigantesca coincidencia.

\section{AgRADECIMIENTOS}

Esta investigación se llevó a cabo durante mi estancia como Investigador Invitado en el Instituto de Estudios culturales cristianos de la Universidad de Seisen (Tokio, 2014-2015) y gracias al Proyecto de Investigación: «Fama, teatro y poder en el Siglo de Oro a través de la obra de Lope de Vega» (RYC-2011-08295, Ministerio de Economía y Competitividad) y una Ayuda para movilidad internacional del personal dedicado a la investigación (V Plan Propio, Universidad de Sevilla).

No quisiera pasar la oportunidad de dejar por escrito mi más sincero agradecimiento a los profesores Akira Sugiyama (Universidad), Fumihiko Takeda (Instituto) y Taro Nagano (Departamento) por su gentileza, paciencia y generosidad, así como al Padre Emilio Martínez, O. P., misionero en Japón como Orfanell, por su valiosa ayuda.

\section{BibliografíA}

Aduarte, D. 1640. Historia de la provincia del Santo Rosario de la Orden de predicadores en Filipinas, Japón y China. Manila: Luis Beltrán.

Asensio, E. 1981. «Tramoya contra poesía. Lope atacado y triunfante (1617-1622)», en M. Sito Alba (pról.). Actas del Coloquio Teoría y realidad en el teatro español del siglo XVII. La influencia italiana (Roma, 16 al 19 de noviembre de 1978): 257-270. Roma: Instituto Español de Cultura y de Literatura de Roma.

Bershas, H. 1963. "Lope de Vega and the Post of Royal Chronicler». Hispanic Review 31: 109-117.

Boxer, Ch. R. 1951. The Christian Century in Japan: 1549-1650. Binghamton: University of California Press.

Cabezas, A. 1995. El siglo ibérico del Japón. Valladolid: Instituto de Estudios Japoneses-Universidad de Valladolid.

Carreño, A. 2013. «... 'También sé yo escribir prosa historial cuando quiero': El triunfo de la fe en los reinos del Japón de Lope de Vega», eHumanista 24: 43-59.

Castilla Pérez, R. 2001. «Los mártires del Japón: ¿Lope de Vega o Mira de Amescua?», en R. Castilla Pérez y M. González Dengra (eds.), La teatralización de la historia en el Siglo de Oro español. Actas del III Coloquio en Granada del 5 al 7 de noviembre de 1999 y cuatro estudios clásicos sobre el tema. Granada: Universidad de Granada: 129-146.

\footnotetext{
107 Ibídem: 162.
}

Civil, P. 2005. "L'actualité des martyrs de la foi: le Triunfo de la fe en los reinos del Japón de Lope de Vega (1618)», en P. Civil (coord.), L'actualité et sa mise en écriture aux $X V^{e}-X V l^{e}$ et $X V I I^{e}$ siècles: Espagne, Italie, France et Portugal: 191-202. París: Presses de la Sorbonne Nouvelle.

Daza, J. M. 2014. "Contexto crítico y polémico de los comentarios manuscritos a las Soledades (1613-1624)». e-Spania 18.

Elvira, M. 2014. "Del Parecer al Examen: circunstancias de escritura de las dos intervenciones del Abad de Rute en la polémica gongorina». e-Spania 18.

Entrambasaguas, J. 1946. Estudios sobre Lope de Vega. Madrid: CSIC.

Espinel, J. L. 1995. San Esteban de Salamanca. Historia y guía (siglos XIII-XX). Salamanca: Editorial San Esteban.

Fernández, L. 1994. "Las misiones de Indias y extremo Oriente vistas por un sobrino de san Ignacio, fray Martín Ignacio de Loyola, 1584». Hispania Sacra 46 (94): 519-528.

Fernández Navarrete, D. 1676. Tratados históricos, políticos y éticos y religiosos de la monarquía de China. Madrid: Imprenta Real.

Fernández Navarrete, D. 1679. Controversias antiguas y modernas de la misión de la gran China. Madrid: S. I.

Francisco Javier, Santo 1944-1945. «Carta a Ignacio de Loyola (Bolonia, 1.3.1540)», en G. Schurhammer y J. Wicki (eds.). Epistolae S. Francisci Xaverii alique eius scripta, I, 29-30. Roma: Monumenta Historica Societatis lesu.

Gil, J. 1991. Hidalgos y samuráis. España y Japón en los siglos XVI y XVII. Madrid: Alianza editorial.

González-Barrera, J. 2009. «De pelícanos, turcos y monjas: a vueltas con la polémica de las Soledades». Anuario Lope de Vega 15: 113-125.

González-Barrera, J. 2011. Expostulatio Spongiae. Fuego cruzado en el nombre de Lope. Kassel: Edition Reichenberger.

Goñi Gaztambide, J. 1979. «El licenciado Pedro Fernández Navarrete: su vida y obras (1564-1632)». Berceo 97: 27-48.

Hsu, C. Y. 2007. "El Japón de Bernardino de Ávila Girón», en Beatriz Mariscal (coord.). Actas del XV Congreso de la Asociación Internacional de Hispanistas "Las dos orillas". Monterrey, México, del 19 al 24 de julio de 2004, II: 227-244. México: Fondo de Cultura Económica.

Jacinto Orfanell, Beato 1633. Historia eclesiástica de los sucesos de la cristiandad de Japón. Madrid: Viuda de Alonso Martín.

Jacinto Orfanell, Beato 1989. Cartas y relaciones. José Delgado García y Manuel González Pola (eds.). Madrid: Instituto de Filosofía y Teología "Santo Tomás".

Lázaro Pulido, M. et al. 2011. El cristianismo en Japón. Ensayos desde ambas orillas. Cáceres: Instituto Teológico San Pedro de Alcántara.

López-Bueno, B. 2011. «El cruce epistolar entre Lope y Góngora de 1615-1616. Revisión de fechas», en El Poeta Soledad. Góngora. 1609-1615. Zaragoza: Prensas Universitarias de Zaragoza.

Martínez Vigil, R. 1884. La Orden de predicadores: sus glorias en santidad, apostolado, ciencias, artes y gobierno de los pueblos. Madrid: Imprenta de Antonio Perci Dubrull.

Muñoz, H. 1963. Semblanzas misioneras. Vida y escritos del Padre Juan de Rueda. Madrid: Separata de Missionalia Hispanica.

Muñoz, H. 1965. Los dominicos españoles en Japón (s. XVII). Madrid: Raycar (Separata de Missionalia Hispanica).

Muñoz, H. 1967. Epistolario de los mártires de Japón. Manila: s. e.

Ocio, H. y Neira, E. 2000. Misioneros dominicos en el Extremo Oriente: 1587-1835. Manila: Life Today Publications.

Pagès, L. 1870. Histoire de la religion chrétienne au Japon depuis 1598 jusqu'a 1651. París: Charles Douniol.

Palomo, F. 2005. «Corregir letras para unir espíritus. Los jesuitas y las cartas edificantes en el Portugal del siglo XVI». Cuadernos de Historia Moderna. Anejos 4: 57-81.

Rodríguez Rodríguez, I. y Álvarez Fernández, J. 1993. Historia de la provincia agustiniana del santísimo nombre de Jesús de Filipinas. Bibliografía España-México. Volumen VI. Valladolid: Arnoldus Press.

Takizawa, O. 2010. La historia de los Jesuitas en Japón. Alcalá de Henares: Servicio de Publicaciones de la Universidad de Alcalá. 
Takizawa, O. 2012. Japón, país del oro. Madrid: Archivo de la frontera (Colección Clásicos mínimos).

Tsai, S. H. 2009. Maritime Taiwan. Historical encounters with the East and the West. Armonk: M. E. Sharpe.

Tubau, X. 2010. «Temas e ideas de una obra perdida: la Spongia (1617) de Pedro Torres Rámila». Revista de Filología Española 90/2: 303-330.

Valignano, A. 1954. Sumario de las cosas del Japón (1583). Adiciones al Sumario de Japón (1592). José Luis Álvarez-Taladriz (ed.). Tokyo: Sophia University.
Vega, L. de 1963. Triunfo de la fee en los reynos del Japón. J. S. Cummins (ed.). Londres: Tamesis Books.

Vega, L. de 2006. Los mártires del Japón. Christina H. Lee (ed.). Newark: Juan de la Cuesta.

Vega, L. de. 2008. Epistolario I (1604-1633), en A. Carreño (ed.), Obras completas de Lope de Vega. Prosa. III. Madrid: Biblioteca Castro (Turner).

Willeke, B. 1985. "Relación del P. Sebastián de San Pedro, O. F. M., sobre los comienzos y las causas de la grande persecución de los cristianos en el Japón (1614)». Archivum Franciscanum Historicum 78: 29-97. 